\title{
Sport pro všechny? Sociální nerovnosti a sportovní aktivity ${ }^{1}$
}

\author{
Sport for All? Social Inequalities and Sport Activities \\ Ondřej Špaček
}

\begin{abstract}
Traces of the social inequalities in the field of sport are one of the key topics of sociology of sport. However, the brief review of sport policy shows that despite general proclamation only little attention is paid to leisure sport, if ever than mostly in the context of non-competitive sport participation of the young, in the lesser extent also of the elderly. The empirical evidence shows wide differentiation of sport participation along age, gender, socioeconomic status and the place of residence. The upper middle class, male and inhabitants from bigger cities are more likely to sport than others. The international comparison reveals that the level of inequalities in sport activity in Czech Republic is rather average in the European context. The evidence indicates that the infrastructural barriers could be more important especially for the inhabitants of rural municipalities, and also that habitus of lower classes disregards sport activities in general. More complex research using qualitative methodology should further develop this question to be more able to specify the importance and the nature of existing barriers to sport participation in Czech Republic.
\end{abstract}

KEYWORDS sport participation, social stratification, leisure, sport for all

\section{Úvod}

Rekreační sport či pohybové aktivity² patří v současné době $\mathrm{k}$ významným způsobům trávení volného času. Přestože pozornost, která je jim obecně věnována, je zastíněna fascinací vrcholovým sportem, reálně se jedná o činnost, které se věnuje značná část populace. Podpora sportovních aktivit bývá zdůvodňována nejen pozitivním dopadem na zdravotní stav populace, ale též osobnostním rozvojem, integračním potenciálem i ekonomickým přínosem (Evropská komise 2007).

Sociální studia. Katedra sociologie FSS MU, 1/2011. S. 53-78. ISSN 1214-813X.

1 Stat' vznikla s podporou grantu MŠMT ČR (identifikační kód 2D06014). Oběma anonymním recenzentům a především také editorům tohoto čísla patří poděkování za kritické a podnětné připomínky k původní verzi textu.

2 Sport je v tomto textu chápán v širším pojetí, tedy nejen ve smyslu soutěživých her, ale též dalších pohybových aktivit spojených s rekreací, zábavou či udržováním kondice. Na druhou stranu hlavním záměrem zde není zkoumat pohybový režim obecně, tedy včetně pohybových aktivit vykonávaných z pracovních, přepravních či jiných důvodů. 
Česká sociologie sportu se prioritně zaměřuje na studium vrcholového, případně výkonnostního sportu, při kterém otevírá především otázky spojené s jeho organizací, medializací, diváctvím či jeho dalšími aspekty (Sekot 2004, 2008). Volnočasovému rekreačnímu sportu je pozornost věnována pouze okrajově, většinou v souvislosti s jeho socializační a integrující rolí, popř́ípadě je sport spojován se zmíněným pozitivním vlivem na zdravotní stav populace (např́klad Slepičková 2001, 2005).

Tento pohled implicitně vychází ze strukturně funkcionalistického paradigmatu, jež bylo charakteristické především pro počáteční období sociologie sportu (Frey a Eitzen 1991, Donnelly 2003). Až následná kritická pozice si začala podrobněji všímat př́tomných konfliktů a nerovností. Ty přitom můžeme chápat jako odraz celkové struktury společnosti, nebo sport považovat za relativně autonomní oblast, která se ale svým uspořádáním též aktivně podílí na udržování stávající podoby společnosti, včetně případných nerovností (Washington a Karen 2001, Collins 2004).

Aniž by bylo nutné vyvracet obecně zmiňované pozitivní aspekty sportování, je tedy vhodné věnovat pozornost také potenciálním dimenzím sociální nerovnosti, které mohou prostupovat sportovní participací. Některé skupiny využívají svůj volný čas ke sportování častěji než jiné, část populace pak nesportuje vůbec. Tyto rozdíly mohou přinášet neočekávané důsledky pro efektivitu využití finanční podpory sportu z veřejných prostředků, mohou mít významné implikace pro obecně proklamovaný univerzalismus sportu, stejně jako mohou být i jedním ze zdrojů vlivu socioekonomického statusu na zdravotní stav (viz Kreidl 2008).

\section{Sociální nerovnosti ve výzkumech sociologie sportu}

Výzkumy české populace podávají přesvědčivý obraz o přetrvávajících rozdílech v míře sportovních aktivit u různých skupin obyvatel. Několik reprezentativních výzkumů prokázalo očekávatelný pokles sportovních aktivit s rostoucím věkem respondentů (Jansa a kol. 2005; Teplý, Adamec a Bunc 1990; Zich a Ungr 1995). V těchto výzkumech je také patrná vyšší účast můžu na sportovních aktivitách než žen. Menší pozornost byla věnována roli sociokulturního prostředí v utváření odlišných dispozic ke sportování. Teplý, Adamec a Bunc (1990) prokázali silnou diferenciaci pohybového režimu v závislosti na dosaženém vzdělání, Špaček (2009, 2010) ukázal na výraznou podmíněnost sportování ve volném čase sociální strukturou české společnosti, přičemž relativní rozdíly mezi různými sociálními kategoriemi jsou stejné i při srovnání se situací před rokem 1989. V roce 2007 měl vysokoškolák při zohlednění ostatních charakteristik skoro desetkrát vyšší šanci, že bude sportovat, než ten, kdo dosáhl pouze základního vzdělání. Obdobně šanci, že budou sportovat, měli muži dvakrát vy̌̌ší než ženy a respondenti ze trrídy odborníků více než dvakrát vyšší než dělníci.

České poznatky o odrazu sociálních nerovností ve sportovní aktivitě jsou pritom v souladu se situací v jiných zemích. Jako klíčové faktory ovlivňující participaci na sportovních aktivitách se prokázaly sociokulturní kontext a pohlaví např́íklad v Belgii (Scheerder, Vanreusel a Taks 2005), Británii (Warde 2006) či USA (Wilson 2002).

Hlavní teoretickou oporou pro pochopení významu rozdílů ve sportování se staly myšlenky Bourdieua (1978, 1998; Hughson, Inglis a Free 2005), který považoval distinktivní charakter životního stylu za základní moment stratifikace společnosti. V každé sociální pozici si 
totiž osvojujeme určitý habitus formující nejen to, co můžeme dělat, ale i to, co bychom chtěli dělat, jak aktivity jiných vnímáme a co při tom cítíme (Bourdieu 1998). Vyšší střední třída tak preferuje sporty vynikající lehkostí, elegancí a rozvahou, v nichž se tělo pohybuje se samozřejmostí. Oproti tomu habitus dělnické tř́ídy upřednostňuje instrumentálně zaměřené pohybové aktivity s okamžitým uspokojením a fyzickým kontaktem. Mezi těmito dvěma póly je pozice nižší střední tř́ídy, jež aspiruje na pozice vyšší stř̌ední trrídy. Naplňuje proto étos odříkání a odkládání současného uspokojení s myšlenkou na budoucí odměnu (Bourdieu 1978; Hughson, Inglis a Free 2005).

Empirické analýzy pak ukazují konkrétní mapu stratifikace jednotlivých sportovních aktivit v různých časových řezech a v kontextu různých společností (Scheerder a kol. 2002, Stempel 2005). Distinktivní charakter jednotlivých sportů je nepochybně situačně podmíněn, protože jejich sociální význam je utvářen relačně (tj. ve vzájemném vztahu $\mathrm{k}$ ostatním prvkům sociálního prostoru) (Bourdieu 1998). Př́ímé přejímání sociální pozice aktivit zjištěných ve výzkumech $\mathrm{v}$ jiných společnostech nemusí být odůvodněné, byt' je samozřejmě možné počítat s určitým vzájemným ovlivňováním např́íc společnostmi. ${ }^{3}$

S ohledem na dosavadní výzkum si tato stat' klade za cíl upozornit na, v české společnosti méně reflektovaný, vztah mezi sociální strukturou společnosti a sportováním. Nejprve stručně charakterizujeme vývoj prostředí, $v$ jehož kontextu se sportování české populace odehrává. Zaměříme se přitom na otázku široké sportovní participace, a to jak z hlediska jejího ideového pozadí, tak z pohledu její praktické podpory skrz organizační strukturu a finanční zázemí sportu. Nízká relevance $\mathrm{v}$ praxi přisuzovaná rekreačnímu sportu je dána do kontrastu s empirickými výsledky, které ukazují na sociální podmíněnost rozdílů ve sportovní participaci. Následující mezinárodní srovnání tuto sociální podmíněnost umist'uje do kontextu ostatních evropských zemí.

Přestože se v textu zaměřujeme především na oblast rekreačního sportu, nelze ji v popisu českého sportovního prostř̌edí zcela odlišit od sportu výkonnostního. Sportovní organizace obvykle nemají jednoznačné zaměření a převládající představa implicitně chápe sport ve starším, pyramidovém pojetí. Podle tohoto modelu představuje rekreační sport základnu, na které stojí další patra sportovní participace, až po nejvýše postavený, vrcholový sport. ${ }^{4}$ Zároveň jsou použitá empirická data $\mathrm{v}$ tomto smyslu limitovaná a zohledňují pouze frekvenci, nikoli charakter sportovních činností.

3 Hluboké proměny, jakými může projít podoba a sociální význam jedné sportovní disciplíny, ilustruje např́iklad Numerato (2009a) na př́kladu českého jachtingu. I když jeho analýza př́mo nesleduje linii stratifikace a sociální exkluzivity, ukazuje, jak úzce mohou být podoba a chápání sportu provázány s konkrétním sociálním, ekonomickým a kulturním kontextem.

4 Tento koncept byl kritizován a oproti němu byla zdůrazněna zásadní dichotomie mezi rekreačním a soutěžním sportem. Tyto odlišné formy sportovní participace mají zcela odlišné cíle a prostředky naplňování, nelze je tedy chápat hierarchicky, ale jako alternativy. Kritici pak často považují volnočasový sport za určitý lék na neduhy, které do pohybové kultury přináší sport vrcholový (Vanreusel, Taks a Renson 2002: 382-383). 


\section{Kontext}

\section{Myšlenka sportu pro všechny}

Moderní sport v sobě nese implicitní rozpor. Na jedné straně je nerozlučně spjatý se soutěživostí, snahou vyniknout a vyhrát, na druhé straně je také formován osvětovými tělovýchovnými ideály co nejširší participace. Přestože zájem o vrcholové soutěže může být chápán jako cesta k vlastnímu sportování, lze říci, že elitářské zaměření na výkon je obvykle v konfliktu s ideály masového či rekreačního sportu.

V českém prostředí lze počátky rekreačního sportu a pohybových aktivit v podobě, v jaké je známe dnes, vysledovat do 19. století. Symbolizuje je především organizace Sokol, která byla založena nejen na ideálech pohybové aktivity, ale též zahrnovala silný výchovný, politický i společenský prvek. Považovat účast v tehdejším Sokole za způsob trávení volného času v dnešním slova smyslu může být do jisté míry problematické, protože byla spíše chápána jako samozřejmá součást mravní či vlastenecké povinnosti než jako ryze volnočasová činnost. Masovým zapojením obyvatelstva do pohybových aktivit ale Sokol vytvořil základ pro jejich další vývoj.

Sokolská tělovýchova koncem 19. století získala silného konkurenta ve vznikajícím olympijském hnutí, které bylo spojeno se sportem jakožto soutěží. Olympijské hnutí mělo a nadále má ambivalentní pozici vzhledem ke snaze o co nejširší sportovní participaci. Na jednu stranu mu byl jeho zakladatelem Coubertinem vtisknut princip universalismu, který tak významně přispěl $\mathrm{k}$ dalšímu zpo̊sobu přemýšlení o sportovní tematice. ${ }^{5} \mathrm{Na}$ druhou stranu s sebou princip soutěže nutně nese určitou výlučnost. ${ }^{6}$ Tento rozpor se projevil i ve vlažném až negativním přijetí olympijské myšlenky českým Sokolem (Kössl 1996). ,[Z]atímco sokolem lze být jen v týmu, sportovec je vždycky sám“ (Kosatík 2010: 85).

Na mezinárodní úrovni tato problematická podoba vrcholového sportu, jenž se svým elitním charakterem čím dál více vzdaloval od sportu rekreačního (Dovalil 2004: 129-130), $\mathrm{v}$ druhé polovině 20. století postupně vyústila do formování výrazného hnutí bojujícího za prosazení pohledu na sport také jako na rekreační aktivitu. Kromě vzniku mezinárodních organizací zabývajících se touto problematikou (TAFISA, FISpT) se otázkou demokratizace sportu začaly zabývat také organizace se širší působností. V roce 1975 přijala Rada Evropy dokument nazvaný Evropská charta sportu pro všechny (Rada Evropy 1975) řadící možnost sportovní participace mezi lidská práva. Na základě tohoto dokumentu byla později formulována a přijata Radou Evropy Evropská charta sportu (Rada Evropy 1992), ve které vlády

5 Zároveň je ale třeba poznamenat, že i u Coubertina se jednalo o universalismus značně selektivní. Např́íklad výrazně odmítal aktivní účast žen na olympijských hrách (Kay 2003: 90).

6 Mezinárodní olympijský výbor kvůli problematickému naplňování univerzalistického odkazu olympismu zformuloval v 90. letech dokonce zvláštní program nazvaný „sport pro všechny“ (Dovalil 2004: 131-132). Ve svých dokumentech chápe „sport pro všechny“ jako „hnutí prosazující olympijskou myšlenku, že sport je všeobecné lidské právo bez ohledu na rasu, sociální třídu či pohlaví. Toto hnutí podporuje sportovní aktivity, které mohou být provozovány lidmi všeho věku, obou pohlaví a s různým sociálním či ekonomickým zázemím“ (IOC 2010). Přes tuto silnou deklaraci je samozřejmě otázkou, nakolik jsou olympiády schopny přispět k rozšiřování rekreačních sportovních aktivit. 
mimo jiné deklarují svoji snahu podporovat širokou sportovní participaci a rozvíjení sportovní infrastruktury.

V českém prostředí byly tyto dokumenty legislativně zohledněny při př́ípravě Národního programu rozvoje sportu pro všechny a následně i zákona o podpoře sportu (č. 115/2001 Sb.). Rekreační sport by tak měl být podporován jak ze strany státu (především MŠMT), tak prostřednictvím jednotlivých krajských a obecních samospráv. Přes tuto deklaraci se ale nejedná o dominantní téma, které by se objevovalo prí diskuzích o sportovní politice. Naprosto výjimečně je pak vnímána i otázka sociálně podmíněných rozdílů míry sportovní participace.

\section{Organizace sportu}

Snaha rozšriřit sport a pohybové aktivity $\mathrm{v}$ populaci byla $\mathrm{v}$ českých zemích $\mathrm{v}$ počátku silně spjata s již zmíněnou Českou obcí sokolskou. Tato organizace vytvořila rozsáhlou sít' tělocvičných jednot, jejiž činnost byla podpořena dobrou materiální základnou i v menších obcích republiky (Kössl, Štumbauer a Waic: 125-127). Jakožto největší sportovní organizace v tehdejším Československu byla po komunistickém převratu v roce 1948 využita jako zastřešující orgán pro nové centralizované řízení sportovních aktivit podle sovětského vzoru. ${ }^{7}$ Jednalo se o radikální přerušení demokratických spolkových aktivit, které bylo spojeno $\mathrm{s}$ přechodem $\mathrm{k}$ důrazu na vrcholový sport a unifikovaný masový sport. Tím se v 50 . letech odklonil vývoj organizace sportu v Česku od zemí západní Evropy (Slepičková 2007a). Československý svaz tělesné výchovy byl jedinou zastř̌šující sportovní organizací a měl v gesci starost o sportování od vrcholové úrovně až po masovou rekreaci. Masový sport byl pěstován se silně ideologickým podtextem a obvykle podle formálních kvantitativních ukazatelů (Kössl, Štumbauer a Waic: 152). Přesto lze říci, že díky existující tradici byly podmínky masového sportu v Československu mezi zeměmi východního bloku ještě relativně „přijatelné“" (Foldesi 1991: 244).

Po pádu komunistického režimu v roce 1989 se sice centralizovaný systém českého sportovního prostředí rozpadl do řady různých menších organizací a zájmových skupin (Slepičková 2007b), avšak je otázkou, nakolik se podařilo navázat na tradice z předkomunistické doby. Reálným problémem zde může být výrazná generační diskontinuita a nedostatečný potenciál oslovit dnešní mládež. Přestože je tedy počet spolků a organizací věnujících se sportovním činnostem poměrně vysoký, nelze na základě kvantitativního úsudku předpokládat, že prostředí zdejší občanské společnosti je obdobné jako v západních zemích, kde spolková tradice nebyla narušena čtyřmi dekádami komunistického režimu.

$Z$ větších zastř̌ešujících organizací patří pouze několik mezi ty, které se primárně věnují podpoře a propagaci rekreačního sportu. Česká asociace sportu pro všechny (ČASPV) sdružuje organizace orientované na nevrcholový sport s důrazem na zdravotní kondici a relaxaci. Do své činnosti zahrnuje široké pole pohybových aktivit (např́klad jóga, tanec, cvičení rodičů s dětmi). Podle stanov je cílem organizace „umožnit tělovýchovné a sportovní vyžití

7 V roce 1952 byl Sokol zrušen a nahrazen Státním výborem pro tělesnou výchovu a sport, předchůdcem Československého svazu tělesné výchovy. Sokolská organizace tímto zanikla až do svého obnovení v roce 1989. 
všem občanům bez ohledu na jejich schopnosti, věk a sociální postavení“ (ČASPV 2007: 1). Tradiční tělovýchovná organizace Sokol je již od počátku zaměřena na co nejširš̌ sportovní participaci (ČOS 2004). Otázku sportu pro všechny pokrývá prostřednictvím tzv. odboru všestrannosti a chápe ji jako zpř́stupnění sportu veřejnosti bez ohledu na výkon a věk. ČASPV a Sokol vzhledem ke sdílenému zaměření na rekreační sport dokonce uvažovaly při vyčleňování sportovních organizací po roce 1989 o vzájemném sloučení. Vzhledem k silné tradicionalitě Sokola se ale osamostatnily jako dvě nezávislé organizace (Slepičková 2007b: 104). Výrazně méně rozšiřrená organizace Orel svoji aktivitu zakládá především na vymezení se vůči vrcholovému sportu. Opřena o křestanské hodnoty si klade za cíl sportem výchovně působit na mládež a děti (Orel, nedatováno: 2). Nejvlivnější sportovní organizace Český svaz tělesné výchovy (ČSTV) naopak sdružuje členy zaměřené na soutěžní výkonnostní sport.

Současné prostředí volnočasového sportu je charakteristické tím, že tradiční sportovní organizace (Sokol, sportovní kluby) ztratily své výsadní postavení. Podstatný podíl sportovních aktivit se dnes odehrává neorganizovaně, individuálně či v neformálním kruhu zájemců. Stejně tak existuje řada soukromých sportovních zařízení zaměřených ve výsledku především na ziskovost. Tato situace má důsledky pro potenciál tradičních sportovních organizací oslovit veřejnost a klade také nové nároky na rozvoj sportovní infrastruktury.

\section{Financování sportu}

Organizační struktura sportu je úzce spojena i s jeho finanční podporou, měli bychom proto alespoň v krátkosti zmínit některá specifika českého modelu veřejného financování sportu. Veřejnou podporu rekreačního sportování v současném modelu organizace sportovních aktivit utváŕí především tři druhy subjektů - stát, samosprávy a sportovní organizace. ${ }^{8}$ Již zde je nutné podotknout, že nezvyklým prvkem českého financování sportu je to, že sportovní organizace nejsou pouze př́ijemci veřejné podpory, ale také prostřednictvím své částečné finanční autonomie tuto podporu utvářejí. Plné vlastnictví akciové společnosti Sazka dává sdruženým sportovním organizacím možnost př́imo rozhodovat o využití rozdělovaného zisku této společnosti. Stát je tím částečně vyřazen z rozhodovacích procesů o směřování těchto nemalých prostředků (Slepičková 2007b: 112). ${ }^{9}$

Přímé státní dotace směřují především do reprezentačního sportu a do sportovní infrastruktury, byt’ část zdrojů je vyhrazena i na rekreační sport (Neshybová 2006: 32). Státní politika tak má vzhledem k objemu poskytnutých prostředků spiše doporučující charakter. Podle Národniho programu rozvoje sportu pro všechny, který vymezuje zásady státní dotační

8 Zde se zaměřujeme výhradně na veřejné zdroje financování. Obecně se na financování sportovních aktivit kromě uvedeného podílí také soukromé firmy prostřednictvím marketingových akcí, umíst’ování reklamy či naplňování principů společenské odpovědnosti. Velmi významným zdrojem jsou samožrejmě též jednotlivci a domácnosti provozující sport (více viz Novotný 2000).

9 Zároveň je třeba poznamenat, že samotné sportovní svazy nepředstavují jednotné a hladce fungující organizace. Tření a bariéry mezi místní a národní úrovní přinášejí mnohé neshody, nespokojenosti či kladou přkkážky efektivitě (podrobně viz Numerato 2008). To patří mezi důvody, proč samotné sportovní organizace mohou být nespokojeny nejen s objemem rozdělovaných prostředkủ, ale také se způsobem rozdělování. 
podpory rekreačního sportu (MŠMT 2009), jsou určeny až čtyři pětiny objemu finančních prostř̌edků směřovaných do této oblasti na sport dětí a mládeže do 18 let a jednorázové otevřené sportovní akce bez jednoznačného zaměření. Pouhých $5 \%$ prostředků je věnováno na sportování občanů starších 60 let. $Z$ celkového rozpočtu MŠMT je v oblasti sportu nejvíce prostř̌edků vyčleněno na rozvoj a údržbu sportovních zařízení (Neshybová 2006: 32), přičemž není jasné, nakolik tato podpora zasahuje i rekreační sport (viz také Flemr 2009).

Významnější roli ve financování hrají krajské a obecní rozpočty, které mají podporu sportu předepsanou dokonce ze zákona (Zákon o podpoře sportu č. 115/2001 Sb.). Její konkrétní organizace a podoba ale není upřesněna a role samosprávy tak bývá velmi různorodá (Numerato 2009b, Slepičková 2007b). Krajské samosprávy své rozhodování obvykle nezakládají na jasně formulované sportovní politice. Významnou roli zde naopak hrají osobní vazby a lobbing. Disproporční množství prostředků z rozpočtu často směřuje do komerčních vrcholových fotbalových a hokejových klubů v duchu politického klientelismu (Numerato 2009b). V současné době nelze očekávat, že by mezi samosprávami na krajské i obecní úrovni byl významně rozšiřen progresivní typ podpory, který zdůrazňuje propojení se zdravotní a sociální tematikou a bývá výrazně orientován na rekreační sport (tamtéž).

Jak již bylo řečeno, hlavní sportovní organizace nejsou pouze př́jemci státní podpory, ale prostřednictvím svého vlastnictví společnosti Sazka také významně spoluurčují charakter podporovaných činností. Výše uvedený přehled směřování těchto organizací ale ukázal, že pouze malá část $\mathrm{z}$ nich se ve své aktivitě zaměřuje na rekreační sport. Jedná se o Českou obec sokolskou, Českou asociaci sportu pro všechny a Orel o. s., jejichž podíl na akciích Sazky tvoří dohromady necelých $20 \%$ (ČOS - 13,54\%; ČASPV - 5,56\%; Orel - 0,88 \%). Z nich pouze ČASPV a Orel ve svých základních dokumentech jasně formulují problematiku rekreačního sportování i v kontextu sociálních nerovností. Informace o tom, jak velké prostředky rozdělované ze zisku Sazky směřují na podporu rekreačního sportu, nejsou známé. Vzhledem $\mathrm{k}$ uvedeným údajům a tomu, že ostatní sportovní organizace uvádějí mezi svými cíly především podporu zájmu svých členů, nelze předpokládat, že by se jednalo o zásadní př́íspěvek.

Na základě představené situace rekreačního sportu v ČR si proto klademe otázku, jaký význam má sociální diferenciace pro rozdíly ve sportování české populace? Jakou roli v těchto rozdílech lze připsat infrastrukturním podmínkám, které bývají tematizovány při formulaci veřejné podpory, a jakou roli hrají kulturní rozdíly mezi skupinami, na které upozorňuje sociologická teorie? Pro hlubší posouzení významnosti našich zjištění nás také bude zajímat, jakou pozici má v tomto ohledu Česká republika v kontextu ostatních evropských zemí a v čem spočívají její specifika.

\section{Data a metoda}

Pro analýzu sportovních a pohybových aktivit jsou vhodná data z výzkumu Eurobarometer 62.0 (2004), která byla sebrána ve všech členských státech EU. ${ }^{10}$ Částečně též využiváme data

10 Evropská komise: Eurobarometer 62.0: Standard European Union Trend Questions and Sport, October-November 2004. Sběr dat TNS OPINION \& SOCIAL, organizováno EOS GALLUP 
z aktuálního šetření Eurobarometer 72.3 (2009). ${ }^{11}$ Do analýzy byly zahrnuty všechny státy Evropské unie, přičemž země, které jsou při výzkumu Eurobarometeru rozděleny na více částí (Německo, Velká Británie), byly sloučeny a váženy v poměru odpovídajícímu populační velikosti těchto částí. Ve všech zemích byli z dat vybráni pouze respondenti, kteří dosáhli alespoň 26 let. Mladší populace ještě často nedokončila formální vzdělávání, což znemožňuje konstruovat proměnnou socioekonomického postavení. Studenti také představují specifickou část populace, která je ještě silně zapojována do sportovních aktivit prostřednictvím nejrůzněǰš́ch školních sportovních programů. Rozdíly ve sportovní participaci se proto projeví nejvýrazněji až po opuštění školního prostředí. ${ }^{12}$

$Z$ věcného hlediska je podstatné nejen rozlišení toho, zda jedinec sportuje či nesportuje, ale i frekvence této aktivity. Pro účely analýzy proto byly u proměnné sledující sportovní aktivitu respondentů rozlišeny tři úrovně hodnot - pravidelné sportování (alespoň jednou za týden), př́iležitostné sportování (méně než jednou za týden) a nesportující (nikdy). ${ }^{13}$ Lze předpokládat, že zatímco př́ležitostně sportující respondenti se sportu věnují pouze rekreačně, zahrnuje kategorie pravidelně sportujících jak rekreační, tak výkonnostní sportovce. ${ }^{14}$ Na základě těchto hodnot byly konstruovány dvě míry sportování v populaci. Míra sportovni participace představuje podíl těch, kteří sportují pravidelně či příležitostně. Má především sociální význam, nebot' ukazuje, nakolik je sport exkluzivním způsobem trávení volného času, ke kterému mají některé skupiny zhoršený př́stup. Druhá míra pravidelného sportování je vypočtena pouze jako podíl těch, kteří sportují pravidelně. Tato míra má blíže ke zdravotnímu pohledu na sportovní problematiku, nebot' týdenní pravidelnost se, alespoň částečně, blíží obecným doporučením o zdravotně žádoucí intenzitě fyzické aktivity (Nelson a kol. 2007).

Mezi sledované sociodemografické charakteristiky patří věk, pohlaví, bydliště a socioekonomické postavení respondenta. Věk byl kategorizován do tří věkových skupin s ohledem

EUROPE, Brusel, vyžádáno a koordinováno Evropskou komisí, Directorate General Press and Communication, Opinion Polls. ZA4229, Kolín, Německo: GESIS-ZA, 2007.

11 Evropská komise: Eurobarometer 72.3, October 2009. Sběr dat TNS OPINION \& SOCIAL. GESIS Kolín ZA4977, verze 1.0.0, 2010. Vzhledem k tomu, že datový soubor Eurobarometer 72.3 je stále ve stadiu před uvolněním (pre-release), je využíván pouze pro analýzu otázek, které nejsou ve starším datovém souboru obsaženy.

12 Srovnáme-li u věkové kategorie 18-25 let studující a pracující, dospějeme již k výrazným rozdílům ve sportovní aktivitě i při malém vzorku, který poskytuje reprezentativní soubor ČR. Zatímco v prŕípadě studentů participují v zásadě všichni a více než tři čtvrtiny sportují pravidelně, u pracujících participuje na sportovních aktivitách sice až $90 \%$ respondentů, pravidelně ale pouze necelých $40 \%$. Tento rozdíl lze samozřejmě částečně vysvětlit sportovními aktivitami, které jsou součástí studijního kurikula.

13 Frekvence sportovní aktivity byla zjištována otázkou „Jak často cvičíte nebo provozujete nějaký sport?““. Je zř̌jmé, že formulace této otázky může ovlivnit, které činnosti respondenti do odpovědi zahrnou a které již nikoli. Problematické z hlediska zařazení můžou být naprríklad aktivity typu jízda na kole, turistika či plavání. Z jiných analýz ale plyne, že i při použití odlišných formulací zůstávají výsledky obdobné (Špaček 2009, 2010).

14 Kategorie respondentů sportujících alespoň jednou týdně zahrnuje jak pravidelné účastníky rekreačního sportu, tak výkonnostní sportovce. Oproti tomu vrcholoví sportovci vzhledem ke svému podílu v populaci pravděpodobně relevantně nezasahují do analyzovaných dat. 
na nejnižší věk souboru (26-44 let, 45-64 let a 65 let a starší), protože analýza tím získá větší citlivost $\mathrm{k}$ př́padným nelineárním závislostem. Při analýze jsme ověřili, že použitím kategorizovaného věku se kvalita modelu oproti jeho spojité podobě nezhorší. Pohlaví je dichotomickou proměnnou, která byla zakódována podle zvyklostí (referenční kategorie „muž“). Místo bydliště rozlišuje tři kategorie př́ímo odpovídající znění otázky v dotazníku zjištující subjektivní zařazení respondenta (venkov, malé nebo středně velké město, velké město).

Způsob měření socioekonomického postaveni si vynucuje alespoň krátkou diskuzi. V českém prostředí bylo prokázáno, že dosažené vzdělání je výrazně lepším prediktorem sportovní aktivity než tř́́dní zařazení prostřednictví EGP (Špaček 2010), avšak data Eurobarometeru zachycují dosažené vzdělání způsobem, který je pro naše účely nedostatečný (věk ukončení školní docházky). Socioekonomické postavení je proto měřeno prostřednictvím současného, př́ípadně posledního zaměstnání. Při dotazování bylo rozlišeno pouze několik hrubých kategorií, které ve výsledku umožnily vytvořit pouze velmi jednoduchou klasifikaci. Odlišujeme tedy vyšší stř̌ední trrídu (vedoucí pozice, střední management a odborníci), nižší stř̌ední třídu (živnostníci, úř́edníci, zaměstnanci ve službách) a nižší tř́ídu (dělníci, zemědělci). ${ }^{15}$ Jakkoliv je toto členění nedostatečné z hlediska specializovaných stratifikačních šetření, pro účely tohoto článku je použitelné a umožňuje utvořit konzervativní odhad vlivu sociálního postavení na sportovní aktivity. Je pravděpodobné, že za použití přesnějšího měření by byl výsledný vliv sociální pozice vyšší.

Analýza diferenciace sportovních aktivit v České republice byla provedena binární logistickou regresí. Tato obdoba lineární regresní analýzy je vhodná $\mathrm{v}$ př́ípadě dichotomických závisle proměnných (Řeháková 2000). V našem př́padě se jednalo o dichotomie „sportuje alespoň někdy/nesportuje nikdy“ (sportovní participace) a „sportuje pravidelně/méně často“" (pravidelné sportováni). Obdobně by problém bylo možné řešit multinomickou či ordinální logistickou regresní analýzou. Uvedený postup jsme se rozhodli použít, protože bylo záměrem zachovat ordinální logiku vysvětlované proměnné a zároveň jsme předpokládali možnou existenci odlišných vzorců sportovní aktivity na obou měřených úrovních.

Při mezinárodním srovnání vzorců sociální podmíněnosti sportování jsme použili jednodušší přístup založený na bivariátních korelacích mezi sociodemografickými charakteristikami respondentů a úrovní jejich sportovní aktivity. $\mathrm{K}$ tomu nás vedla především snaha zprůhlednit metodu výpočtu a vyhnout se vícerozměrnému př́stupu v situaci, kdy výsledné hodnoty slouží jako vstupní data pro další krok analýzy. Pro měření vztahu mezi proměnnými byl použit korelační koeficient Somersovo $d$, který je vhodný pro ordinální proměnné

15 Klasifikace kategorií zaměstnání (podle původního znění v dotazníku Eurobarometer): vyšši středni třída - vrcholný management a ředitelé (generální ředitelé, ředitelé obecně, jiní ředitelé); střední management, jiní manažeři (vedoucí oddělení, učitel, technik); majitel firmy, vlastník (úplný nebo společník) podniku; profesionál (právník, lékař, účetní, architekt...); zaměstnaný profesionál (zaměstnaný lékař, právník, účetní, architekt); nižši středni třída - vlastník prodejny, řemeslník nebo jiná samostatně výdělečně činná osoba; zaměstnanec, pracující hlavně stacionárně (na jednom místě); zaměstnanec, ne stacionární, ve službách (nemocnice, restaurace, policie, hasiči); zaměstnanec, ne stacionární, ale na cestách (obchodní zástupce, řidič...); kontrolor; nižši třída kvalifikovaný dělník; jiní (nekvalifikovaní) dělníci, služebnictvo; zemědělec; rybář. 
a zároveň má asymetrickou logiku výpočtu (rozlišuje závisle a nezávisle proměnné) (Garson 2008). Ve všech př́padech vystupovala jako závisle proměnná sportovní aktivita respondentů.

Pro vytvoření přehledné typologie zemí Evropské unie z hlediska vzorců sportovních aktivit byla použita metoda hierarchického shlukování. Shlukování bylo provedeno na základě proměnných měřících podmíněnost sportovní aktivity jednotlivými sociodemografických charakteristikami (korelační koeficienty) a celkového podílu sportovně aktivních respondentů. ${ }^{16}$ Při vytváření typologie tedy hrály roli jak sociálně diferencované vzorce sportování, tak celková míra sportování v celé populaci. Shlukování bylo prováděno Wardovou metodou, blízkost zemí byla měřena čtvercem euklidovské vzdálenosti.

Pro výpočty a zpracování dat byl použit program SPSS, shlukovací analýza byla provedena v programu R (R Development Core Team 2010) s použitím modulu cluster (Maechler a kol. 2005).

\section{Výsledky}

Základní pohled na účast na sportovních aktivitách české populace přesvědčivě ukazuje existenci předpokládaných rozdílů. Alespoň někdy se ke sportování dostane $60 \%$ obyvatel starších 26 let, přičemž méně než polovina z nich sportuje pravidelně $(26 \%$ z celkového počtu). Sledujeme-li sociodemografické charakteristiky, pak nejvýrazněji je sportovní participace diferencována podle věku a socioekonomického postavení. V nejmladší věkové kategorii do 44 let sportují celé tři čtvrtiny populace (75\%), u střední věkové kategorie (45- 64 let) se již jedná pouze o $55 \%$ a z lidí starších 65 let sportuje už jen $38 \%$. Sociální pozice také výrazně ovlivňuje sportování, z respondentů zařazených do vyšší střední tř́́dy sportují opět tři čtvrtiny (75 \%), u nižší střední tř́ídy je to o něco méně (65\%) a v př́ípadě dělníků se pak nejedná ani o polovinu (43\%). Menší rozdíly ve sportování je možné najít mezi muži a ženami a mezi městem a venkovem. Mužů alespoň někdy sportuje $65 \%$, zatímco žen pouze $55 \%$. Ve velkých a malých městech je obdobná míra sportovni participace dosahující príbližně dvou třetin (68\%, respektive $62 \%$ ), ve venkovských sídlech pak pouze poloviny (50\%).

Rozdíly v pravidelném sportováni jsou podobné, ovšem vyskytují se zde některé zaznamenatelné odlišnosti. Podíl pravidelně sportujicich ve střední věkové kategorii je prakticky stejný jako u nejvyšší věkové kategorie $(20 \%)$. Ve větších městech patří více sportujících mezi pravidelné sportovce (až $55 \%$ ) než v malých městech (42\%) či na venkově (32\%). Stejně tak mezi sportující vyšší střední tríídou najdeme více respondentů s pravidelnou intenzitou sportování (57\%) než v obou zbývajících tř́dách (okolo $38 \%$ ). Tyto odlišnosti jsou podrobněji popsány a statisticky testovány dále.

16 Podílu sportovně aktivních byla v procesu shlukování přisouzena dvojnásobná váha. Tím bylo dosaženo, že měl alespoň poloviční váhu oproti vzorcům rozdílů ve sportování, které reprezentovaly čtyři proměnné (vzorce podle věku, pohlaví, bydliště a socioekonomického postavení). 
Graf 1: Sportovní aktivita české populace podle sociodemografických charakteristik

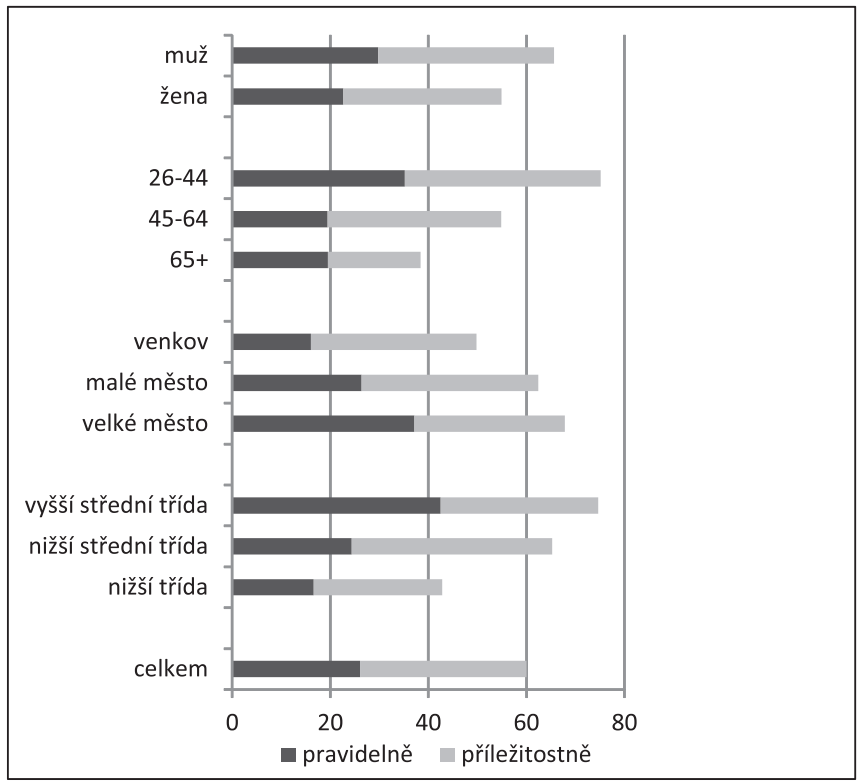

Zdroj dat: Eurobarometer 62.0; $\mathrm{N}=821$.

Logistická regresní analýza umožňuje vypočítat čistý vliv jednotlivých faktorů ovlivňujících závisle proměnnou. Mưžeme tedy říci, zda mají muži vyšší šanci, že budou sportovat, než ženy, i když zohledníme odlišnou věkovou a sociální strukturu obou těchto skupin. Provedli jsme dvě oddělené binární logistické regrese, v prvním př́ipadě byly zjišt’ovány šance, že respondent se zařadí alespoň do kategorie sportovní participace oproti nesportování. Druhá regrese se zaměřila na pravidelné sportování oproti méně intenzivní participaci (včetně nesportování).

Logistická analýza v zásadě potvrdila existenci rozdílů ve sportovní participaci, tak jak je ukázal graf 1. Věk patří mezi nejvýraznější činitele snižující sportovní participaci. Lidé prostřední věkové kategorie (45-64 let) mají oproti nejmladším přibližně poloviční šanci $(0,40)^{17}$, že budou sportovat (tabulka 1$)$. Stejný pokles pak je mezi nejstarší a prostřední věkovou kategorií, ve výsledku tak mají lidé z nejstarší věkové kategorie přibližně čtvrtinovou šanci $(0,22)$, že budou sportovat, oproti těm nejmladším. Socioekonomické postavení má obdobně významný vliv jako věk. Příslušníci nižší střední třídy mají více než dvakrát vyšší šanci $(2,33)$, že budou sportovat než nižší třída, vyšší střední třída pak skoro 3,5krát $(3,39)$. Menší význam má pohlaví a místo bydliště. Ženy mají nižší šanci, že budou sportovat než muži $(0,67)$, ve městech je zase sportovní participace pravděpodobnější než na venkově, a to bez rozdílu velikosti města $(1,54$; respektive 1,62$)$.

17 Uvedená čísla v závorkách udávají tzv. poměr šancí, tedy jak se změní šance sportovní participace při přechodu mezi uvedenými kategoriemi. 
Tabulka 1: Logistická regrese - sportovní partic ipace ${ }^{a}$

\begin{tabular}{|c|c|c|c|c|}
\hline & B & S.E. & Sig. & $\operatorname{Exp}(B)$ \\
\hline Konstanta & 0,76 & 0,30 & 0,01 & 2,13 \\
\hline Věk ${ }^{b}$ & & & 0,00 & \\
\hline $45-64$ & $-0,91$ & 0,18 & 0,00 & 0,40 \\
\hline $65+$ & $-1,53$ & 0,21 & 0,00 & 0,22 \\
\hline Pohlaví (ženy) & $-0,40$ & 0,16 & 0,01 & 0,67 \\
\hline Bydlištěc & & & 0,03 & \\
\hline malé město & 0,43 & 0,18 & 0,02 & 1,54 \\
\hline velké město & 0,48 & 0,22 & 0,03 & 1,62 \\
\hline Socioekonomické postaveníd & & & 0,00 & \\
\hline nižší střední trída & 0,84 & 0,18 & 0,00 & 2,33 \\
\hline vyšší střední tríida & 1,22 & 0,22 & 0,00 & 3,39 \\
\hline Nagelkerkeho $\mathrm{R}^{2}$ & 0,20 & & & \\
\hline Predikce (pouze s konstantou / výsledný model) & 60,0 & $\% /$ & 68,2 & $\%$ \\
\hline \multicolumn{5}{|l|}{$N=976$} \\
\hline \multicolumn{5}{|c|}{$\begin{array}{l}\text { a) Sportuje alespoň někdy / nesportuje. } \\
\text { b) Referenční kategorie „26-44 let“. } \\
\text { c) Referenční kategorie "venkov“. } \\
\text { d) Referenční kategorie "nižší trída". } \\
\text { Charakteristiky modelu: všechny uvedené modely binární logistické regrese jsou podle hodnoty chí } \\
\text { kvadrátu statisticky signifikantně ( } p<0,05 \text { ) odlišné od modelü zahrnující pouze konstantu a podle Hosmer- } \\
\text { Lemeshowa testu se modelovaná data neliši od reálných dat ( } p>0,05) \text {. Prediktivní síla modelü (podíl } \\
\text { správně klasifikovaných prípadů) není výrazná. }\end{array}$} \\
\hline
\end{tabular}

Zdroj dat: Eurobarometer 62.0.

Druhá logistická regrese se zaměřuje na vysvětlení vzorců pravidelného sportování. Klíčové jsou především odlišnosti od předchozího modelu. Kromě logicky menší pravděpodobnosti pravidelného sportování oproti pouhé sportovní participaci (vyjádřeno nižší hodnotou konstanty) lze rozpoznat následující rozdíly (tabulka 2): Stejně jako v předcházejícím př́ípadě s rostoucím věkem klesá šance na pravidelné sportování, avšak zlom nastává pouze mezi nejmladší a prostřední věkovou kategorií. Dále zůstává tato šance stejná. Rozdíl mezi pravidelným sportováním mužů a žen nedosahuje hranice statistické významnosti, stejně jako méně výrazné odlišnosti mezi nižší střední a nižší třídou. Vyšší střední třída však zůstává výrazně odlišná, šance na pravidelné sportování je zde skoro třikrát vyšší než u nižší třídy $(2,79)$. Výraznější odstupňování se oproti sportovní participaci objevuje v rozdílech mezi městem a venkovem. Bydlení ve velkém městě oproti venkovu zvyšuje více než dvakrát $(2,34)$ šanci na pravidelné sportování. ${ }^{18}$

18 Další srovnání sportovní participace a pravidelného sportování může poskytnout třetí regresní model, který v subpopulaci sportujících hledá determinanty toho, že respondent bude sportovat pravidelně. Výsledná specifikace tohoto modelu je uvedena v př́loze 1 . Je v souladu s výše popsanými rozdíly. 
Tabulka 2: Logistická regrese - pravidelné sportová nía

\begin{tabular}{|c|c|c|c|c|}
\hline & B & S.E. & Sig. & $\operatorname{Exp}(B)$ \\
\hline Konstanta & $-1,15$ & 0,33 & 0,00 & 0,32 \\
\hline Věkb & & & 0,00 & \\
\hline $45-64$ & $-0,75$ & 0,19 & 0,00 & 0,47 \\
\hline $65+$ & $-0,77$ & 0,24 & 0,00 & 0,46 \\
\hline Pohlaví (ženy) & $-0,28$ & 0,17 & 0,09 & 0,75 \\
\hline Bydlištěc & & & 0,00 & \\
\hline malé město & 0,56 & 0,22 & 0,01 & 1,74 \\
\hline velké město & 0,85 & 0,24 & 0,00 & 2,34 \\
\hline Socioekonomické postaveníd & & & 0,00 & \\
\hline nižšís střední tř́da & 0,37 & 0,21 & 0,08 & 1,45 \\
\hline vyšší střední trída & 1,03 & 0,23 & 0,00 & 2,79 \\
\hline Nagelkerkeho $\mathrm{R}^{2}$ & 0,13 & & & \\
\hline Predikce (pouze s konstantou / výsledný model) & 74,0 & $\% /$ & 75,3 & $\%$ \\
\hline \multicolumn{5}{|l|}{$N=976$} \\
\hline $\begin{array}{l}\text { a) Sportuje alespoň jednou týdně / sportuje mén } \\
\text { b) Referenční kategorie "26-44 let". } \\
\text { c) Referenční kategorie "venkov". } \\
\text { d) Referenční kategorie "nižši tř́da". } \\
\text { Charakteristiky modelu: Viz tabulka l. }\end{array}$ & & & & \\
\hline
\end{tabular}

Zdroj dat: Eurobarometer 62.0.

Srovnání vzorců diferenciace sportovní participace a pravidelného sportování umožňuje zvýraznit některá specifika pravidelného sportu. Podle analyzovaných dat je pravidelná forma sportování oproti nepravidelné formě více netečná vůči stárnutí, spíše ji najdeme ve městech a u vyšší střední třídy. Mezi nejmladší a prostřední věkovou kategorií lze sice pozorovat podobný pokles jako v př́ípadě sportovní participace, v seniorském věku už ale pravidelné sportování dále neklesá. Pravidelná forma sportování či cvičení může být významnější součástí habitu, a je tedy odolnější vůči fyziologickým překážkám, které se v souvislosti se stárnutím objevují. Je ovšem třeba poznamenat, že rozdílnost významu věku pro pravidelné sportování a pro sportovní participaci je na hranici statistické významnosti a ověrení této teze si vyžaduje provést další analýzy.

Pravidelné sportování je méně diferencované podle sledovaných charakteristik než sportovní participace. V prípadě sportovní participace dosahuje regresní model hodnoty Nagelkerkeho $\mathrm{r}^{2}$ 0,20, zatímco u pravidelného sportování pouze $0,13 .{ }^{19}$ Pouze charakter bydliště ovlivňuje pravidelné sportování výrazněji než sportovní participaci.

19 Nagelkerkeho $\mathrm{r}^{2}$ je nejpoužívanější aproximace tradičního $\mathrm{r}^{2}$ používaného $\mathrm{v}$ lineární regresní analýze (Řeháková 2000). 


\section{Subjektivní vnímání bariér}

Samotné sociodemografické vzorce sportovních aktivit pouze naznačují zdroje bariér, které mohou stát v cestě snahám rozšírít sportování mezi co nejširší vrstvy populace. Přestože hledání těchto překážek lze pouze stěží založit na datech ze standardizovaného dotazování, lze se zde pokusit alespoň o základní obraz. Základní zjištění analýzy ukazuje, že respondenti přičítají nesportování spíše vlastnímu nezájmu než nedostatku míst pro sportovní aktivity $(59 \%$ oproti $36 \%$, tabulka 3$){ }^{20}$

Nedostatek prríležitostí je považován za velmi silnou překážku především ve venkovských obcích (64\%) a částečně též u nižších tříd. Oproti tomu socioekonomické postavení je velmi silně svázáno právě s nezájmem o sportovní aktivity. Respondenti z nižší tř́ídy ho vyjadřují výrazně častěji (72\%) než respondenti nižší stř̌ední (57\%) či dokonce vyšší tř́́dy (47\%). Nezájem o sportovní a pohybové aktivity také stoupá s rostoucím věkem respondentů.

Tabulka 3: Bariéry sportovních aktivit ( $\vee \%$ )

\begin{tabular}{|c|c|c|}
\hline & Nedostatek príležitostía & Nemá zájem \\
\hline Muž & 38 & 60 \\
\hline Žena & 35 & 59 \\
\hline $26-44$ & 37 & 49 \\
\hline $45-64$ & 38 & 64 \\
\hline $65+$ & 30 & 68 \\
\hline Venkov & 64 & 63 \\
\hline Malé/střední město & 21 & 58 \\
\hline Velké město & 14 & 55 \\
\hline Vyšší střední trída & 28 & 47 \\
\hline Nižší střední třída & 36 & 57 \\
\hline Nižší třída & 42 & 72 \\
\hline Celkem & 36 & 59 \\
\hline $\mathrm{N}$ & 912 & 936 \\
\hline
\end{tabular}

Zdroj dat: Eurobarometer 72.3 .

20 Tento rozdíl potvrzuje i přímá otázka po příčinách toho, že respondent nesportuje více. Odmyslíme-li si neurčité vyjádření o nedostatku času (50,5\%), nemohoucnost či nemoc (18,5\%) a ostatní, blíže nespecifikované důvody $(8,3 \%)$, představuje neoblíbenost sportovních aktivit další nejčastěji uváděný důvod (7,9\%). Oproti tomu nedostatek dostupných zařízení uvádělo pouze $4,8 \%$ respondentů. 
Z deklarací samotných respondentů tedy lze identifikovat dvě základní bariéry sportovní participace, které jsou úzce spojeny se sociální diferenciací. Zaprvé je zde patrná značná nespokojenost se sportovní infrastrukturou v malých venkovských obcích. Další výzkum by mohl ukázat, zda tento nedostatek souvisí s rozdrobeností sídelní struktury a nedostatečnou obslužností, či zda zde roli hraje i špatné zaměření existujících zařízení, kdy fotbalová hřiště či starší sokolovny neslouží jako vhodné zázemí pro současné podoby rekreačního sportu (viz Flemr 2009).

Druhý významný faktor je úzce spojen se sociálním postavením a naznačuje oprávněnost chápat sportovní aktivity jako činnosti obzvláště spojené s habitem. Koncept habitu zdůrazňuje přirozenost, kterou př́islušníci určité sociální skupiny přikládají svému distinktivnímu vnímání okolního světa. Př́islušníci nižší tř́ídy si tedy podle analyzovaných dat osvojili pohled na sportovní aktivity jako na něco, co není zajímavé či zábavné. Ve sportování jim proto nemusí bránit relativně objektivní překážky, jakými jsou např́klad infrastrukturní či ekonomické podmínky, ale především to, že sportovat nechtějí.

\section{Mezinárodní srovnání}

Zjištěný vztah mezi sociální diferenciací a pohybovými aktivitami v českých podmínkách se nyní pokusíme zařadit do mezinárodního kontextu. Toto srovnání je vzhledem $\mathrm{k}$ omezenému rozsahu nutně provedeno pouze $\mathrm{v}$ hrubých číslech a je třeba ho chápat i s určitou rezervou, jako výchozí bod pro prŕpadné podrobnější analýzy rozdílných situací a politik uvnitř Evropské unie. Pro hodnověrnou interpretaci odlišného významu sledovaných sociodemografických faktorů na sportovní aktivitu by bylo třeba popsat podrobně specifika sociální, demografické a geografické struktury jednotlivých zemí. Stejně tak způsob, jakým organizace sportu ovlivňuje vztah mezi sociální strukturou a rekreačním sportováním, by vyžadoval podrobný srovnávací pohled (viz např́ílad DaCosta a Miragaya 2002).

Mezi volnočasovou sportovní aktivitou zemí Evropské unie je možné nalézt výrazné rozdíly (graf 2). Nejvýrazněji vybočují svou sportovní aktivitou obyvatelé skandinávských zemí. Ve Finsku a Švédsku pravidelně sportuje více než $70 \%$ obyvatel, v Dánsku necelých $60 \%$ (alespoň někdy sportuje více než $90 \%$ ve Finsku a Švédsku, $80 \%$ v Dánsku). Sportovní participace ve většině ostatních zemí EU se pohybuje mezi 40 až $60 \%$, nejnižší můžeme najít v Mad'arsku a Portugalsku, kde nedosahuje ani $30 \%$. Obdobně je míra pravidelného sportování v zemích mimo Skandinávii podstatně nižší. Ve většině zemí alespoň jednou týdně sportuje mezi 20 a $40 \%$ obyvatel, na posledních místech tabulky je opět Mad'arsko a Portugalsko s $11 \%$, respektive $14 \%$.

Obecně také platí, že míra sportovni participace je o něco vyšší v zemích původní EU15 (mimo jižní země) a o něco nižší v nových členských státech střední a východní Evropy. Výjimku tvoří Slovinsko, které dosahuje vysoké míry sportovní participace i relativně dobré pozice z hlediska pravidelného sportování. 
Graf 2: Sportovní aktivita v zemích EU (obyvatelé starší 26 let včetně)

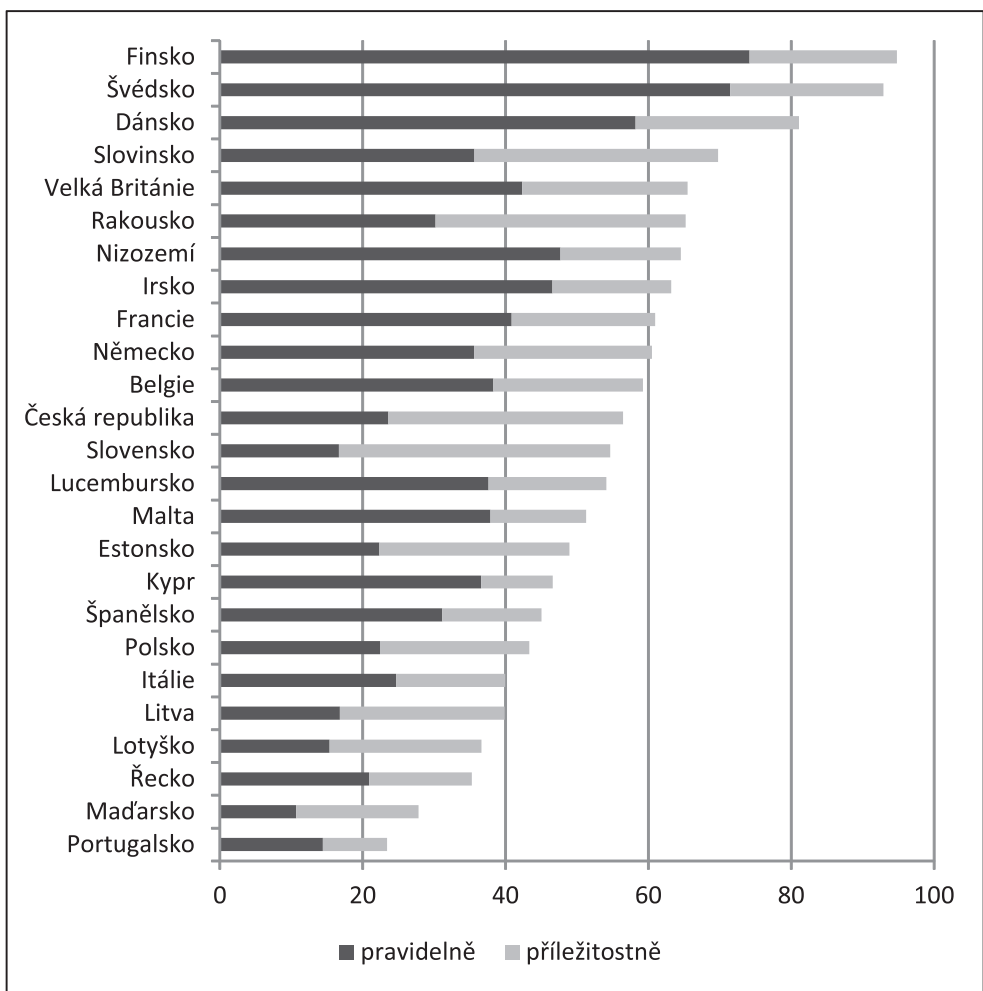

$N=21112$.

Zjednodušená analýza významu jednotlivých faktorů ovlivňujících sportovní aktivitu byla provedena za srovnáním míry závislosti u každé země (viz data a metoda). Narozdíl od regresní analýzy zde není měřený vliv očištěn od vlivu ostatních proměnných. Výsledné korelační koeficienty každého faktoru byly spolu s celkovou mírou sportovní aktivity použity jako klíč pro rozdělení zemí EU do shluků, podle charakteru vzorců sportovní participace a pravidelného sportování (viz též př́loha 2 a 3 ). ${ }^{21}$

$\mathrm{V}$ obou případech byly země rozděleny do tří skupin, byt' toto rozdělení bylo do určité míry předmětem arbitrárního rozhodnutí. Na druhou stranu proces shlukování napovídal, že tři skupiny představují úspornou a zároveň výstižnou typologii (graf 3 a 4).

První skupina zahrnuje země s vysokou mírou sportovní aktivity a zároveň nízkým významem sociodemografických faktorů pro její strukturaci (tabulka 4 a 5). Jedná se o skandinávské země EU (Dánsko, Finsko, Švédsko), částečně sem spadá také Nizozemí, které bylo

$21 \quad$ Z analýzy byl vyřazen Kypr, který svou odlehlou hodnotou míry závislosti sportovní aktivity na charakteru místa bydliště výrazně deformoval výsledky shlukování. Vysvětlení této výchylky přesahuje rámec tohoto článku a vyžadovalo by podrobnou analýzu situace v tomto státě. 
Ondřej Špaček: Sport pro všechny? Sociální nerovnosti a sportovní aktivity

Graf 3: Seskupení zemí podle vzorce sportovní partic ipace

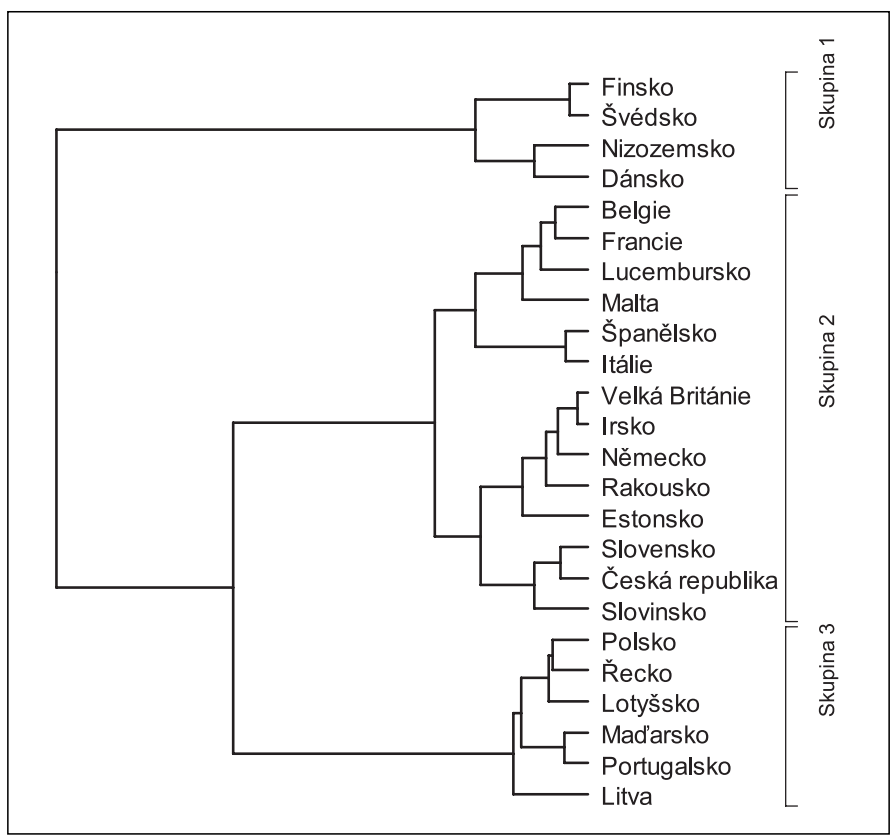

Graf 4: Seskupení zemí podle vzorce pravidelného sportování

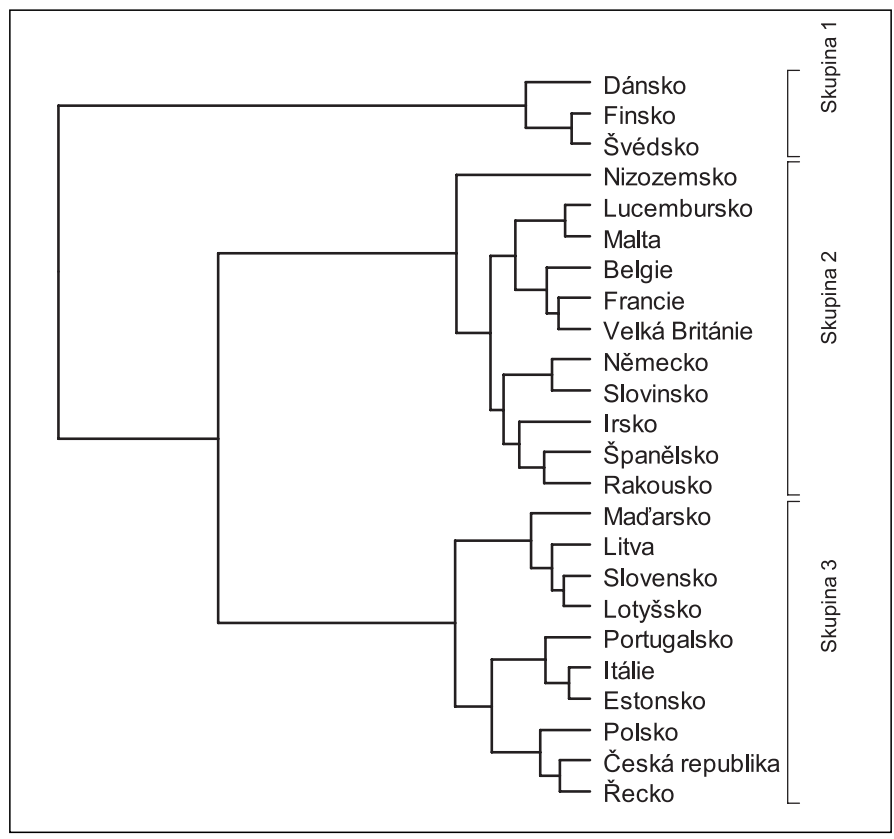


v př́ípadě sportovní participace zařazeno do této skupiny, při posuzování pravidelného sportováni nikoli, i když i zde mělo obdobné charakteristiky.

Druhá a třetí skupina zemí představuje vzájemně méně odlišné typy. Přestože sportovní aktivita obyvatel zemí druhé skupiny je výrazně vyšší než v př́ípadě třetí skupiny, vzorce diferenciací jsou obdobné. Pouze s tím rozdílem, že u třetí skupiny je bydliště výraznějším determinantem a socioekonomické postavení je zde důležitější z hlediska sportovní participace.

Rozdělení zemí mezi druhou a třetí skupinu podle vzorců pravidelného sportováni sleduje poměrně výstižně linii původních členských států EU a nově přistoupivších zemí. Výjimečně se některé nové členské státy zařadily do druhé skupiny s vy̌šśím podílem pravidelně sportujicích (Slovinsko, Malta) a některé jižní státy patř́ do třetí skupiny (Itálie, Portugalsko a Řecko). Typologie podle rozdílů ve sportovní participaci tuto linii sleduje méně. Oproti předcházející variantě patří do druhé skupiny také Česká republika, Estonsko, Itálie a Slovensko.

Tabulka 4: Charakteristika typologie zemí podle sportovní partic ipace

\begin{tabular}{|c|c|c|c|c|c|c|}
\hline & \multirow[b]{2}{*}{$\begin{array}{c}\text { Podíl } \\
\text { sportujících }\end{array}$} & \multicolumn{4}{|c|}{ Korelace } & \multirow[b]{2}{*}{$\mathrm{N}$} \\
\hline & & $\begin{array}{c}\text { Socio- } \\
\text { ekonomické } \\
\text { postavení }\end{array}$ & Pohlaví & Bydliště & Věk & \\
\hline Skupina 1 & $83 \%$ & 0,05 & $-0,03$ & 0,00 & 0,09 & 4 \\
\hline Skupina 2 & $57 \%$ & 0,18 & 0,09 & 0,04 & 0,23 & 14 \\
\hline Skupina 3 & $34 \%$ & 0,24 & 0,07 & 0,13 & 0,24 & 6 \\
\hline ČR & $56 \%$ & 0,21 & 0,08 & 0,13 & 0,24 & skupina 2 \\
\hline
\end{tabular}

Tabulka 5: Charakteristika typologie zemí podle pravidelného sportování

\begin{tabular}{|l|c|c|c|c|c|c|}
\hline \multirow{2}{*}{} & \multirow{2}{*}{$\begin{array}{c}\text { Podíl } \\
\text { sportujících }\end{array}$} & $\begin{array}{c}\text { Socio- } \\
\text { ekonomické } \\
\text { postavení }\end{array}$ & Pohlaví & Bydliště & Věk & $\mathrm{N}$ \\
\hline Skupina 1 & $68 \%$ & 0,08 & $-0,10$ & 0,05 & 0,01 & 3 \\
\hline Skupina 2 & $39 \%$ & 0,12 & 0,04 & $-0,01$ & 0,12 & 11 \\
\hline Skupina 3 & $19 \%$ & 0,13 & 0,04 & 0,07 & 0,11 & 10 \\
\hline & & & & & & 0,11 \\
\hline ČR & $24 \%$ & 0,14 & 0,06 & 0,12 & skupina 3 \\
\hline
\end{tabular}

Česká republika byla z hlediska sportovní participace zařazena do druhé skupiny a z hlediska pravidelného sportováni do třetí skupiny. $\mathrm{V}$ obou prrípadech jsou hodnoty korelačních koeficientů i míry sportovní aktivity typické pro danou skupinu. Výjimku tvoří míra závislosti sportovní aktivity na místě bydliště, která je v Česku o něco vyšší než činí průměr.

Shrneme-li uvedené, lze říci, že výjimečnou skupinu tvoří skandinávské země, které dosahují vysoké pravidelné i nepravidelné sportovní participace a zároveň jsou zde sportovní 
aktivity minimálně sociodemograficky diferencované. Ostatní země jsou si svými vzorci diferenciace poměrně podobné, přičemž kromě specifických odchylek se liší hlavně v celkové míře sportování. Česká republika se z hlediska sportovní participace, tj. př́ležitostného sportování, řadí mezi průměrné země EU. V oblasti pravidelného sportování je její pozice o něco horší a zařazuje se do skupiny zemí s nižší mírou sportovní aktivity. Kromě obvyklého, poměrně vysokého významu socioekonomického postavení a věku pro diferenciaci sportovních aktivit hraje v Česku mimořádnou roli také charakter místa bydliště (nižší míra sportovní aktivity na venkově).

\section{Závěr}

V českém prostředí je idea sportovní participace široké veřejnosti historicky obsažena již od počátku moderního sportu v souvislosti s masovým tělocvičným hnutím Sokol. Jeho myšlenkový odkaz v podobě kolektivní a národnostně motivované participace ale již nemůže v současném kontextu individualizovaných podob trávení volného času obstát. Navíc se ukazuje, že veřejná podpora směřující $\mathrm{k}$ rekreačnímu sportu obvykle nereflektuje otázku genderových a socioekonomických nerovností ve sportovní participaci, které bývají tematizovány v západní Evropě.

Kvantitativní analýza sociální podmíněnosti sportovní aktivity české populace potvrdila dosud zjištěné podstatné rozdíly. Kromě věku patří mezi významné determinanty sportování také socioekonomické postavení, bydliště a pohlaví. V evropském kontextu patř́ Česká republika $\mathrm{z}$ hlediska sportovní aktivity populace $\mathrm{k}$ průměrným zemím, a to i z hlediska sociální podmíněnosti rozdílů ve sportování. Řadí se tak po bok většiny zemí západní Evropy. Narozdíl od řady ostatních postkomunistických zemí zasažených sovětským modelem organizace sportu (Földesi 1991) zde nejspíše sehrála roli již existující sportovní i demokratická tradice. $Z$ evropského průměru vybočuje české prostředí nižší úrovní sportovní participace u obyvatel menších obcí (viz dále).

Odpovědět na otázku, jakým způsobem zohlednit zjištěné rozdíly ve sportovní participaci při tvorbě sportovní politiky, není jednoduché a dalece přesahuje rámec tohoto př́íspěvku. Ze zkušeností jiných evropských států plyne, že úspěšná cesta překonávání nerovností není jedna, stejně tak ale existuje řada neefektivních řešení (DaCosta a Miragaya 2002; Van Tuyckom a Scheerder, nedatováno). Mezinárodní empirické srovnání ukazuje na jednoznačně se vymykající skandinávské země, které svou mírou sportovní participace, ale především i silnou rovností přístupu ke sportu, stojí zcela mimo evropský (a pravděpodobně i světový) kontext. Podstatné je pritom ale i důsledné posouzení podoby sportovní organizace a zohlednění společenského kontextu, kde má kromě sportovní tradice či ekonomické situace velký význam i charakter občanské společnosti či role dobrovolnictví.

$\mathrm{V}$ žádném př́padě se přitom nejedná pouze o objem prostředků věnovaných na podporu sportu, ale i o charakter jejich distribuce. Dosud neexistuje dostatečně podrobná analýza současného financování českého sportu, která by sledovala i účel vynakládaných prostředků. Relevantní hypotéza může být taková, že vzhledem $\mathrm{k}$ institucionálnímu uspořádání sportovní organizace směřuje většina finančních prostředků na podporu již etablované skupiny sportujících, kteří navíc obvykle patří mezi sociálně a ekonomicky lépe postavenou část populace. 
Omezené prostředky by přitom měly být uváženě využívány především tam, kde mohou efektivně přispět ke snížení dopadů sociálních nerovností, protože nezaměřená veřejná podpora sportovních aktivit může sociálně podmíněné rozdíly ve sportovní participaci dokonce posilovat. Skrytou stránkou nerovného přístupu ke sportování může být např́iklad i to, že ženy nejčastěji sportují prostřednictvím komerčně organizovaných aktivit (například wellness cvičení či aktivní dovolené) (Fialová 2003: 109), zatímco mužský dominující sport - fotbal - bývá obvykle vydatně podporován z veřejných prostředků.

Empirická data nám umožnila letmý vhled do možných zdrojů bariér limitujících sportovní participaci. Mohli jsme přitom zkoumat pouze subjektivní pohled respondentů, a to v omezeném spektru, ve kterém jsme porovnávali bariéry infrastrukturní a kulturní. Ukazuje se, že nedostatečná sportovní infrastruktura obvykle nebývá respondenty vnímána jako podstatná překážka rekreačního sportování, v čemž se odráží rozdíl mezi pohledem běžné veřejnosti a některých aktérů sportovní politiky, které ji vnímají naopak jako prioritu (viz Flemr 2009, MŠMT 2009). Na druhou stranu analýza odhalila, že pro obyvatele malých obcí se jedná o silně pocit'ovanou překážku. Problém přitom může být jak v nedostatku infrastruktury, tak v nevhodnosti jejího zaměření vzhledem k současné podobě rekreačního sportu (též Flemr 2009).

Podstatné souvislosti se objevují také při pohledu na kulturní bariéry. Přes jistá omezení jsou data v souladu s předpoklady, které přisuzují různým společenským tř́dám odlišný pohled na sportovní aktivity. Podle Bourdieua (1978) je habitus nižší tř́idy charakteristický instrumentálním pojímáním těla, které se zaměřuje především na schopnost dosahovat praktických cílů. Oproti tomu má pro privilegované třídy tělo hodnotu samo o sobě a obvykle je předmětem celoživotního rozvoje (tělo jako projekt, viz Shilling 1993). Tento rozdíl v pojímání vlastního těla může vést $\mathrm{k}$ tomu, že nižší tř́idy si spojují aktivní sportování spíše s mládeží či vrcholovými soutěžemi a již ho nepovažují za vhodnou náplň volného času v dospělosti. Konfrontace s tezí o rozostřování symbolických významů ve spotřební kapitalistické společnosti (viz Featherstone 1990) může být v rozporu s těmito zjištěními, byt' tyto procesy mohou být zastřeny agregátním pohledem kvantitativní analýzy vedoucí napříč různými generacemi. Osvojený habitus totiž vykazuje vysokou setrvačnost a analýza celé populace tak může odrážet diferenciaci typickou spíše pro socializaci, tak jak probíhala před desítkami let, než pro podmínky současné společnosti. ${ }^{22}$

Dotazníkovým šetřením nelze v úplnosti konkretizovat překážky, které omezují rovný př́stup ke sportovním aktivitám. Naznačené infrastrukturní a kulturní bariéry je možné interpretovat různým způsobem, stejně tak jako by měly být doplněny např́iklad fyzickými, ekonomickými či politickými faktory (Hylton a Totten 2008). Jejich hlubší pochopení je nutné pro získání lepší představy o tom, jakými prostředky by je bylo možné odstraňovat.

22 Aplikace přístupu Bourdieua na reprodukci sociální struktury v kontextu socialistického Československa představuje samostatný problém, na jehož plné rozpracování zde není dostatek prostoru. Lze ale vyslovit domněnku, že v ekonomicky silně nivelizovaném prostředí mohla kulturní diferenciace sehrávat podstatnější roli ve vymezování skupinových identit než tam, kde se společenské rozdíly podstatně vyjadřují i prostřednictvím materiálních statků (srovnej Numerato 2009). 
Další postup si vyžaduje zapojení případových studií komplexně mapujících konkrétní oblasti nerovností, ${ }^{23} \mathrm{~s}$ důrazem na kvalitativní metodologii. Přestože poznatky kvalitativního výzkumu mají vzhledem ke své komplexitě a menší jednoznačnosti obtížnější přístup k implementaci do konkrétních politik (Hylton a Totten 2008: 47-52), jsou z výše uvedených důvodů naprosto nezbytné pro přesnější pojmenování prř́čin a podob nerovností. Není nám přitom známo, že by existovala kvalitativní studie zabývající se dopadem sociálních nerovností na sportovní participaci v prostředí České republiky. Obtížnost přenositelnosti existujících zjištění z jiných sociokulturních kontextů přitom může být posílena specifickou podobou a vývojem české sportovní organizace v postkomunistické společnosti.

Snížení nerovností ve sportovní participaci je žádoucí pro naplnění univerzalistických ideálů, které patři mezi silné legitimizační prostředky sportu. Rovnost šancí, at' už se jedná o fair play v samotné sportovní soutěži, ale právě tak i o možnost „účastnit se“, dává sportu oprávnění nárokovat si místo mezi výdobytky civilizace. Více či méně zřetelné bariéry sportovní participace tuto rovnost narušují, a mohou tak být prostředkem pro zpochybnění adekvátnosti plošné veřejné podpory veskrze soukromé volnočasové aktivity. V neposlední řadě ale může také vhodné nastavení sportovní politiky, směřující ke snížení rozdílů ve sportovní participaci, přispívat $\mathrm{k}$ redukci sociálních nerovností v celé společnosti a přispět $\mathrm{k}$ její integraci (Hylton a Totten 2008: 59).

\section{Literatura}

BOURDIEU, Pierre. Sport and Social Class. Social Science Information, 1978, č. 17, s. 819-840.

BOURDIEU, Pierre. Teorie jednání. 1. vyd. Praha: Karolinum, 1998.

COLLINS, Mike. Sport, Physical Activity and Social Exclusion. Journal of Sports Sciences, 2004, č. 22, s. 727-740.

ČASPV. Stanovy České asociace Sport pro všechny, občanské sdružení. 2007. [Cit. 2010-05-06]. Dostupné na www: <caspv.cz/cz/o-nas/dokumenty/stanovy-dokumenty-smernice/>.

ČOS. Stanovy České obce sokolské. 2004. [Cit. 2010-05-06]. Dostupné na www: < sokol-cos.cz/COS/ sokol.nsf/080e8cc1106e3ab3c1256ef80070017e/a6abb75b87c08a00c12573230042c6cb?OpenDo cument>.

DACOSTA, Lamartine Pereira; MIRAGAYA, Ana. Worldwide Experiences and Trends in Sport for All. Aachen: Meyer \& Meyer Sport, 2002.

DONNELLY, Peter. Sport and Social Theory. In HOULIHAN, B. Sport and Society: A Student Introduction. London: Sage, 2003, s. 11-27. ISBN 0-7619-7034-7.

DOVALIL, Josef. Sport pro všechny jako součást olympijského hnutí. Olympismus. Praha: Olympia, 2004, s. 129-136. ISBN 80-7033-871-7.

EVROPSKÁ komise. Bílá kniha o sportu. Brusel: Komise Evropských společenství, 2007.

EVROPSKÁ komise. Eurobarometer 72.3. Results for Czech Republic. 2010. [Cit. 2010-05-20]. Dostupné na www: <ec.europa.eu/public_opinion/archives/ebs/ebs_334_fact_cz_en.pdf $>$.

FEATHERSTONE, Mike. Perspectives on Consumer Culture. Sociology, 1990, č. 5, s. 5-22.

FIALOVÁ, Ludmila. Women and Sport in the Czech Republic. In HARTMANN-TEWS, I.; PFISTER, G. Sport and Women: Social issues in International Perspective. London: Routledge, 2003, s. 102-117. ISBN 9780415246286.

23 V oblasti romské etnické menšiny viz např́iklad Hastrmanová a Houdek 2007. 
FLEMR, Libor. Sportovní infrastruktura v České republice - současnost a vývojové trendy. In FLEMR, L. a kol. Prostorové podmínky pro podporu aktivního životního stylu současné populace. Praha: Karolinum, 2009, s. 113-137, ISBN 978-80-246-1765-7.

FOLDESI, Gyongyi Szabo. From Mass Sport to the 'Sport for All' Movement in the 'Socialist' Countries in Eastern Europe. International Review for the Sociology of Sport, 1991, č. 26, s. 239-257.

FREY, James H.; EITZEN, D. Stanley. Sport and Society. Annual Review of Sociology, 1991, č. 17, s. 503-522.

GARSON, G. David. Statnotes: Topics in Multivariate Analysis - Ordinal Association. 2008. [Cit. 201005-10]. Dostupné na www: < faculty.chass.ncsu.edu/garson/pa765/statnote.htm>.

HASTRMANOVÁ, Šárka; HOUDEK, Lukáš. Romské etnikum a sport: percepce, př́nosy a omezení. In SLEPIČKOVÁ, I.; FLEMR, L. Aktuálni otázky sociologie sportu. Praha: FTVS UK, 2007, s. 50-55. ISBN 978-80-86317-55-7.

HUGHSON, John; INGLIS, David; FREE, Marcus. Sport, Culture and Embodied Experience. The Uses of Sport. A Critical Study. London: Routledge, 2005, s. 138-158. ISBN 9780415260480.

HYLTON, Kevin; TOTTEN, Mick. Developing 'Sport for All?'. Addressing Inequality in Sport. In HYLTON, K.; BRAMHAM, P. Sports Development: Policy, Process and Practice. 1 vyd. London: Routledge, 2008, s. 42-76. ISBN 9780415421836.

IOC. Sport for All-Olympic.org. 2010. [Cit. 2010-05-06]. Dostupné na www: < olympic.org/en/content/ The-IOC/Commissions/Sport-for-All/?Tab $=0>$.

JANSA, Petr; KOCOUREK, Jan; VOTRUBA, Jan; DAŠKOVÁ, Blanka. Sport a pohybové aktivity $v$ životě české populace. Praha: UK FTVS, 2005.

KAY, Tess. Sport and Gender. In HOULIHAN, B. Sport and Society: A Student Introduction. London: Sage, 2003, s. 89-104. ISBN 0-7619-7034-7.

KOSATÍK, Pavel. České snění. Praha: Torst, 2010. ISBN 978-80-7215-393-0.

KÖSSL, Jiří. Sokol a olympismus. In WAIC, M. a kol. Sokol v české společnosti 1862-1938. Praha: FTVS UK, s. 160-173. ISBN 80-238-3287-5.

KÖSSL, Jiří; ŠTUMBAUER, Jan; WAIC, Marek. Vybrané kapitoly z dějiny tělesné kultury. Praha: Karolinum, 2008. ISBN 978-80-246-1566-0.

KREIDL, Martin. Mohou rozdíly v laickém chápání zdraví vysvětlit rozdíly v subjektivním zdravotním stavu mezi statusovými skupinami? Sociologický časopis, 2008, s. 55-86.

MAECHLER, M.; ROUSSEEUW, P.; STRUYF, A.; HUBERT, M.. Cluster Analysis Basics and Extensions. 2005. Nepublikováno. Dostupné na www: <http://www.r-project.org/>.

MŠMT. Zásady programu V. Národni program rozvoje sportu pro všechny. 2009. [Cit. 2010-05-06]. Dostupné na www: <msmt.cz/uploads/soubory/TVS/2010/Z_5_ZASADY_Program_5_2010_www. doc>.

NELSON, Miriam a kol. Physical Activity and Public Health in Older Adults: Recommendation from the American College of Sports Medicine and the American Heart Association. Circulation, 2007, č. 116, s. 1094-1105.

NESHYBOVÁ, Jarmila. Analýza dotační politiky veřejného sektoru pro oblast sportu. Diplomová práce. Masarykova univerzita v Brně, 2006.

NOVOTNÝ, Jiří. Podpora sportu v ČR. In SLEPIČKA, P.; SLEPIČKOVÁ I. Sport, stát, společnost: studijni materiály. Praha: FTVS UK, s. 233-248. ISBN 80-86317-06-04.

NUMERATO, Dino. Czech Sport Governing Bodies and Social Capital. International Review for the Sociology of Sport, 2008, č. 1, s. 21-34.

NUMERATO, Dino. Revisiting Weber's Concept of Disenchantment: An Examination of the Re-enchantment with Sailing in the Post-Communist Czech Republic. Sociology, 2009a, č. 3, s. $439-456$. 
NUMERATO, Dino. The Institutionalisation of Regional Public Sport Policy in the Czech Republic. International Journal of Sport Policy, 2009b, č. 1, s. 13-30.

OREL. Co je Orel? [On line, cit. 2010-05-20]. Dostupné na www: <orel.cz/profil/cojeorel2.pdf $>$

Rada Evropy. The European Sport for All Charter. 1975.

Rada Evropy. Evropská charta sportu. 1992.

R DEVELOPMENT CORE TEAM. $R$ : A Language and Environment for Statistical Computing. Vídeň: R Foundation for Statistical Computing, 2010. ISBN 3-900051-07-0.

ŘEHÁKOVÁ, Blanka. Nebojte se logistické regrese. Sociologickỳ časopis, 2000, č. 36, s. 475-492.

SEKOT, Aleš. Sociálni dimenze sportu. 1. vyd. Brno: Masarykova univerzita v Brně, Fakulta sportovních studií, 2004.

SEKOT, Aleš. Sociologické problémy sportu. 1. vyd. Praha: Grada, 2008.

SHILLING, Chris. The Body and Social Theory: Theory, Culture \& Society. 1. vyd. London: Sage, 1993. ISBN 0-8039-8585-1.

SCHEERDER, Jeroen; VANREUSEL, Bart; TAKS, Marijke. Stratification Patterns of Active Sport Involvement Among Adults: Social Change and Persistence. International Review for the Sociology of Sport, 2005, č. 40, s. 139-162.

SCHEERDER, Jeroen; VANREUSEL, Bart; TAKS, Marijke; RENSON, Roland. Social Sports Stratification in Flanders 1969-1999: Intergenerational Reproduction of Social Inequalities? International Review for the Sociology of Sport, 2002, č. 37, s. 219-245.

SLEPIČKOVÁ, Irena. Sport a volný čas adolescentů. Praha: FTVS UK, 2001.

SLEPIČKOVÁ, Irena. Sport a volný čas: vybrané kapitoly. 2. vyd. Praha: Karolinum, 2005.

SLEPIČKOVÁ, Irena. From Centralized to Democratic Sport Governance and Organization. Transition, 2007a, č. 47, s. 95-106.

SLEPIČKOVÁ, Irena. Sportovní organizace: teoretická východiska a situace $v \check{C} R$ po roce 1990. Praha: Karolinum, 2007b.

STEMPEL, Carl. Adult Participation Sports as Cultural Capital: A Test of Bourdieu's Theory of the Field of Sports. International Review for the Sociology of Sport, 2005, č. 40, s. 411-432.

ŠPAČEK, Ondřej. Pohybové aktivity a sportování veřejnosti před rokem 1989 a v současnosti. Česká kinantropologie, 2009, č. 13, s. 67-74.

ŠPAČEK, Ondřej. Sport a stratifikace. Česká společnost: hodnoty a kulturní reprodukce. 2010. V recenzi.

TEPLÝ, Zdeněk; ADAMEC, Čeněk; BUNC, Václav. Objem a energetická náročnost tělovýchovy u dospělé populace ČSR. Acta Universitatis Carolinae Gymnica, 1990, č. 26, s. 23-29.

Van TUYCKOM, C.; SCHEERDER, Jeroen. Sport for All? Insight into Stratification and Compensation Mechanisms of Sporting Activity in the EU-27. Přijato k publikování ve Sport, Education and Society.

VANREUSEL, Bart; TAKS, Marijke; RENSON, Roland. Belgium - Flanders: Origins, Development and Trends of Sport for All. In DACOSTA, L. P.; MIRAGAYA, A. Worldwide Experiences and Trends in Sport for All. Aachen: Meyer \& Meyer Sport, 2002, s. 379-400. ISBN 978-18412-60853.

WARDE, Alan. Cultural Capital and the Place of Sport. Cultural Trends, 2006, č. 15, s. 107-122.

WASHINGTON, Robert E.; KAREN, David. Sport and Society. Annual Review of Sociology, 2001, č. 27 , s. $187-212$.

WILSON, Thomas C. The Paradox of Social Class and Sports Involvement: The Roles of Cultural and Economic Capital. International Review for the Sociology of Sport, 2002, č. 37, s. 5-16.

ZICH, František; UNGR, Václav. Postoje české veřejnosti k tělesné výchově a sportu. Tělesná výchova a sport mládeže, 1995, č. 61, s. 1-8. 
SOCIÁLNÍ STUDIA 1/201 1

Př́loha 1: Logistická regrese - pravidelné sportování oproti sportovní partic ipacio

\begin{tabular}{|c|c|c|c|c|}
\hline & $B$ & S.E. & Sig. & $\operatorname{Exp}(B)$ \\
\hline Konstanta & $-0,52$ & 0,37 & 0,15 & 0,59 \\
\hline Věk ${ }^{b}$ & & & 0,05 & \\
\hline $45-64$ & $-0,48$ & 0,21 & 0,02 & 0,62 \\
\hline $65+$ & 0,03 & 0,29 & 0,92 & 1,03 \\
\hline Pohlaví (ženy) & $-0,10$ & 0,19 & 0,60 & 0,91 \\
\hline Bydlištěc & & & 0,01 & \\
\hline malé město & 0,45 & 0,24 & 0,06 & 1,57 \\
\hline velké město & 0,84 & 0,28 & 0,00 & 2,31 \\
\hline Socioekonomické postaveníd & & & 0,02 & \\
\hline nižší střední třída & $-0,10$ & 0,24 & 0,68 & 0,90 \\
\hline vyšší střední třída & 0,53 & 0,27 & 0,05 & 1,70 \\
\hline Nagelkerkeho $\mathrm{R}^{2}$ & 0,08 & & & \\
\hline Predikce (pouze s konstantou / výsledný model) & 56,6 & $\% /$ & 60,8 & $\%$ \\
\hline \multicolumn{5}{|l|}{$N=523$} \\
\hline \multicolumn{5}{|c|}{$\begin{array}{l}\text { a) Sportuje alespoň jednou týdně / sportuje méně často. } \\
\text { b) Referenční kategorie "26-44 let". } \\
\text { c) Referenční kategorie "venkov“. } \\
\text { d) Referenční kategorie "nižší třída“. } \\
\text { Charakteristiky modelu: viz tabulka } 1 .\end{array}$} \\
\hline
\end{tabular}


Ondřej Špaček: Sport pro všechny? Sociální nerovnosti a sportovní aktivity

Přiloha 2: Korelační koeficienty sociodemografických proměnných a sportovní partic ipace $\checkmark$ jednotlivých zemích EU (Somersovo d)

\begin{tabular}{|c|c|c|c|c|c|c|c|}
\hline & \multicolumn{4}{|c|}{ Korelace } & \multirow{2}{*}{$\begin{array}{l}\text { Podíl } \\
\text { sportujících } \\
\text { (v \%) }\end{array}$} & \multirow[b]{2}{*}{$N$} & \multirow[b]{2}{*}{ Skupina } \\
\hline & $\begin{array}{l}\text { Socio- } \\
\text { ekonomické } \\
\text { postavení }\end{array}$ & Pohlaví & Bydliště & Věk & & & \\
\hline Belgie & 0,14 & 0,08 & $-0,05$ & 0,15 & 59 & 849 & 2 \\
\hline Česká republika & 0,21 & 0,08 & 0,13 & 0,24 & 56 & 976 & 2 \\
\hline Dánsko & 0,08 & $-0,05$ & 0,00 & 0,12 & 81 & 909 & 1 \\
\hline Estonsko & 0,17 & 0,03 & 0,02 & 0,32 & 49 & 834 & 2 \\
\hline Finsko & 0,03 & 0,00 & 0,02 & 0,04 & 95 & 883 & 1 \\
\hline Francie & 0,15 & 0,05 & 0,03 & 0,16 & 61 & 835 & 2 \\
\hline Irsko & 0,17 & 0,07 & 0,02 & 0,25 & 63 & 859 & 2 \\
\hline Itálie & 0,20 & 0,15 & 0,02 & 0,22 & 40 & 864 & 2 \\
\hline Kypr & 0,29 & 0,17 & 0,32 & 0,10 & 47 & 440 & - \\
\hline Litva & 0,23 & $-0,02$ & 0,20 & 0,25 & 40 & 815 & 3 \\
\hline Lotyško & 0,19 & 0,09 & 0,13 & 0,28 & 37 & 808 & 3 \\
\hline Lucembursko & 0,18 & 0,14 & 0,03 & 0,13 & 54 & 436 & 2 \\
\hline Mad'arsko & 0,23 & 0,04 & 0,14 & 0,23 & 28 & 899 & 3 \\
\hline Malta & 0,06 & 0,05 & 0,08 & 0,12 & 51 & 425 & 2 \\
\hline Německo & 0,20 & 0,09 & $-0,02$ & 0,22 & 60 & 1316 & 2 \\
\hline Nizozemí & 0,06 & $-0,03$ & $-0,06$ & 0,17 & 65 & 900 & 1 \\
\hline Polsko & 0,29 & 0,08 & 0,11 & 0,25 & 43 & 808 & 3 \\
\hline Portugalsko & 0,23 & 0,08 & 0,11 & 0,24 & 23 & 880 & 3 \\
\hline Rakousko & 0,15 & 0,07 & 0,07 & 0,30 & 65 & 871 & 2 \\
\hline Řecko & 0,26 & 0,14 & 0,11 & 0,22 & 35 & 800 & 3 \\
\hline Slovensko & 0,24 & 0,12 & 0,12 & 0,30 & 55 & 1098 & 2 \\
\hline Slovinsko & 0,23 & 0,14 & 0,09 & 0,27 & 70 & 856 & 2 \\
\hline Španělsko & 0,17 & 0,18 & 0,01 & 0,22 & 45 & 842 & 2 \\
\hline Švédsko & 0,05 & $-0,03$ & 0,02 & 0,02 & 93 & 845 & 1 \\
\hline Velká Británie & 0,17 & 0,05 & 0,01 & 0,25 & 66 & 1064 & 2 \\
\hline
\end{tabular}

$N=21112$

Zdroj dat: Eurobarometer 62.0. 
Přiloha 3: Korelační koeficienty sociodemografických proměnných a pravidelného sportování $\checkmark$ jednotlivých zemích EU (Somersovo d)

\begin{tabular}{|c|c|c|c|c|c|c|c|}
\hline & \multicolumn{4}{|c|}{ Korelace } & \multirow{2}{*}{$\begin{array}{l}\text { Podíl } \\
\text { sportujících } \\
\text { ( } \vee \%)\end{array}$} & & \multirow[b]{2}{*}{ Skupina } \\
\hline & $\begin{array}{c}\text { Socio- } \\
\text { ekonomické } \\
\text { postavení }\end{array}$ & Pohlaví & Bydliště & Věk & & $\mathrm{N}$ & \\
\hline Belgie & 0,15 & 0,06 & $-0,05$ & 0,06 & 0,38 & 849 & 2 \\
\hline Česká republika & 0,14 & 0,06 & 0,12 & 0,11 & 0,24 & 976 & 3 \\
\hline Dánsko & 0,08 & $-0,11$ & 0,05 & 0,05 & 0,58 & 909 & 3 \\
\hline Estonsko & 0,14 & 0,01 & 0,01 & 0,14 & 0,22 & 834 & 3 \\
\hline Finsko & 0,09 & $-0,10$ & 0,04 & 0,00 & 0,74 & 883 & 1 \\
\hline Francie & 0,09 & 0,04 & $-0,04$ & 0,08 & 0,41 & 835 & 2 \\
\hline Irsko & 0,13 & 0,01 & $-0,02$ & 0,19 & 0,47 & 859 & 2 \\
\hline Itálie & 0,15 & 0,03 & 0,04 & 0,15 & 0,25 & 864 & 3 \\
\hline Kypr & 0,22 & 0,11 & 0,28 & 0,06 & 0,37 & 440 & - \\
\hline Litva & 0,08 & 0,03 & 0,10 & 0,04 & 0,17 & 815 & 3 \\
\hline Lotyško & 0,10 & 0,06 & 0,08 & 0,08 & 0,15 & 808 & 3 \\
\hline Lucembursko & 0,10 & 0,04 & 0,05 & 0,11 & 0,38 & 436 & 2 \\
\hline Mad'arsko & 0,06 & 0,02 & 0,02 & 0,08 & 0,11 & 899 & 3 \\
\hline Malta & 0,07 & 0,05 & 0,04 & 0,07 & 0,38 & 425 & 2 \\
\hline Německo & 0,19 & 0,02 & 0,00 & 0,11 & 0,36 & 1316 & 2 \\
\hline Nizozemí & 0,03 & $-0,09$ & $-0,06$ & 0,15 & 0,48 & 900 & 2 \\
\hline Polsko & 0,21 & 0,05 & 0,09 & 0,08 & 0,22 & 808 & 3 \\
\hline Portugalsko & 0,15 & 0,01 & 0,07 & 0,16 & 0,14 & 880 & 3 \\
\hline Rakousko & 0,11 & 0,04 & $-0,02$ & 0,18 & 0,30 & 871 & 2 \\
\hline Řecko & 0,16 & 0,12 & 0,10 & 0,10 & 0,21 & 800 & 3 \\
\hline Slovensko & 0,10 & 0,04 & 0,12 & 0,12 & 0,17 & 1098 & 3 \\
\hline Slovinsko & 0,18 & 0,06 & 0,06 & 0,15 & 0,36 & 856 & 2 \\
\hline Španělsko & 0,10 & 0,14 & $-0,02$ & 0,13 & 0,31 & 842 & 2 \\
\hline Švédsko & 0,07 & $-0,09$ & 0,05 & $-0,03$ & 0,71 & 845 & 1 \\
\hline Velká Británie & 0,12 & 0,07 & $-0,02$ & 0,12 & 0,42 & 1064 & 2 \\
\hline
\end{tabular}

$N=21112$.

Zdroj dat: Eurobarometer 62.0.

\section{Autor}

Ondřej Špaček je asistentem na Fakultě humanitních studií Univerzity Karlovy v Praze a studentem doktorského studia Fakulty sociálních věd Univerzity Karlovy v Praze. Zabývá se problematikou sociálních nerovností ve sportovní participaci a otázkami sociologie města.

Kontakt: ondrej.spacek@fhs.cuni.cz 